Int. J. Electrochem. Sci., 14 (2019) 10819 - 10834

\title{
Activation of Methane on PdZn/C Electrocatalysts in an Acidic Electrolyte at Low Temperatures
}

\author{
J. Nandenha ${ }^{1, *}$, I.H.F. Nagahama ${ }^{1,2}$, J.Y. Yamashita ${ }^{1,2}$, E.H. Fontes ${ }^{1}$, J.M.S. Ayoub ${ }^{1}$, R.F.B. de Souza ${ }^{1}$, \\ F.C. Fonseca ${ }^{1}$, A.O. Neto ${ }^{1, *}$ \\ ${ }^{1}$ Instituto de Pesquisas Energéticas e Nucleares, IPEN/CNEN-SP, Av. Prof. Lineu Prestes, 2242 \\ Cidade Universitária, CEP 05508-000, São Paulo, SP, Brazil \\ ${ }^{2}$ Faculdades Osvaldo Cruz, FOC, Rua Brigadeiro Galvão, 540 Barra Funda, CEP 01151-000, São \\ Paulo, SP, Brazil \\ *E-mail: neto.almir@,bol.com.br
}

doi: $10.20964 / 2019.12 .76$

Received: 5 March 2019 / Accepted: 30 April 2019 / Published: 29 October 2019

$\mathrm{PdZn} / \mathrm{C}$ electrocatalysts were prepared by sodium borohydride utilized as reducing agent for activation methane in an acidic medium at room temperature and in a proton exchange membrane fuel cell (PEMFC) at $80^{\circ} \mathrm{C}$. The materials prepared were characterized by X-ray diffraction (XRD), transmission electron microscopy (TEM) and X-ray photoelectron spectroscopy (XPS). The diffractograms of the $\mathrm{PdZn} / \mathrm{C}$ electrocatalysts showed only peaks associated with $\mathrm{Pd}$ face-centered cubic (fcc) structure. Cyclic voltammograms (CV) of all electrocatalysts after adsorption of methane shown an increment in current during the anodic scan, this effect was more pronounced for $\operatorname{Pd}_{(70)} \mathrm{Zn}_{(30)} / \mathrm{C}$. In situ ATR-FTIR (Attenuated Total Reflectance-Fourier Transform Infrared) experiments was not observed the formation of intermediates adsorbed for $\mathrm{PdZn} / \mathrm{C}$ electrocatalysts, this behavior indicated that the methane oxidation occurs by parallel mechanisms. Polarization curves at $80^{\circ} \mathrm{C}$ in $\mathrm{PEMFC}$ show that $\mathrm{Pd}_{(90)} \mathrm{Zn}_{(10)} / \mathrm{C}$ has superior performance over the other electrocatalysts in methane oxidation.

Keywords: sodium borohydride reduction process; $\mathrm{PdZn} / \mathrm{C}$ electrocatalysts; methane oxidation; acidic electrolytes; polarization curves

\section{FULL TEXT}

(C) 2019 The Authors. Published by ESG (www.electrochemsci.org). This article is an open access article distributed under the terms and conditions of the Creative Commons Attribution license (http://creativecommons.org/licenses/by/4.0/). 